\title{
ERK inhibitor U0126 enhanced SDT-induced cytotoxicity of human leukemia U937 cells
}

\author{
Xiaomin Su, Xiaobing Wang, Kun Zhang, Shuang Yang, Qin Xue, Pan Wang \\ and Quanhong Liu \\ Key Laboratory of Medicinal Resources and Natural Pharmaceutical Chemistry, Ministry of Education, National Engineer- \\ ing Laboratory for Resource Developing of Endangered Chinese Crude Drugs in Northwest of China, College of Life Sciences, \\ Shaanxi Normal University, Xian, Shaanxi, China
}

\begin{abstract}
This study was to investigate the cell killing effect of chlorin-e6 (Ce6)-mediated sonodynamic therapy (SDT) on human leukemia U937 cells and explore the role of ERK signal pathway in the process. The ultrastructure changes of $\mathrm{U} 937$ cells induced by ultrasonic irradiation were evaluated by scanning electron microscope (SEM) and transmission electron microscope (TEM). The viability of cells was evaluated by ViaCount assay. Apoptosis was analyzed using flow cytometer as well as fluorescence microscopy with 4'-6-diamidino-2-phenylindole (DAPI) staining. Western blotting was used to analyze the expression of mitogen-activated protein kinase (MAPK). Intracellular reactive oxygen species (ROS) and mitochondria membrane potential (MMP) levels were also analyzed by flow cytometer after exposure. Our experiments showed that several distinct sonochemical effects were found after Ce6-mediated SDT treatment. Western blotting analysis indicated that the MAPK was activated. Especially, pre-treatment with ERK inhibitor U0126 could additionally enhance SDT-induced cell viability loss, early- and late-apoptotic rate, chromatin condensation, DNA fragmentation and caspase- 3 activation. Besides, a mass of ROS accumulation and a conspicuous loss of mitochondrial membrane potential were detected in U937 cells. These findings suggested ERK signal pathway may deliver a survival signal which counteracts SDT-induced cell death, while combination with U0126 could significantly potentiate the SDT-induced cytotoxic effect in U937 cells.
\end{abstract}

Key words: Sonodynamic therapy - Chlorin-e6 - ERK - Human leukemia U937 cells

\section{Introduction}

Sonodynamic therapy (SDT) is a novel strategy in tumor treatment which shows synergistic effects on cell killing by the combination of a sonosensitizer and ultrasound ( $\mathrm{Yu}$ mita et al. 2007). SDT has been widely examined and many reports demonstrated the synergistic effects of ultrasound and sensitizers in studies on cells in vitro (Yumita et al. 1996, 2002; Yu et al. 2004). In 2000, Ashush et al. first reported that

Correspondence to: Pan Wang, Key Laboratory of Medicinal Resources and Natural Pharmaceutical Chemistry, Ministry of Education, National Engineering Laboratory for Resource Developing of Endangered Chinese Crude Drugs in Northwest of China, College of Life Sciences, Shaanxi Normal University, Xi'an 710062, Shaanxi, China

E-mail: wangpan@snnu.edu.cn therapeutic ultrasound could induce apoptosis in human myeloid leukemic cells (HL-60, K562, and U937 cell lines) (Ashush et al. 2000). In 2002, Lagneaux et al. also presumed that the ultrasonic treatment could be a promising tool for the ex-vivo elimination of leukemic cells by means of apoptosis (Lagneaux et al. 2002).

Recent studies have shown that low-intensity ultrasound could efficiently activate sensitizers and indirectly induce cytotoxic reactive oxygen species (ROS) accumulation and the subsequent cell damage (Hiraoka et al. 2006; Kuroki et al. 2007). In previous studies, we have investigated the combined effect of ultrasound and several sensitizers on distinct tumor cell lines (Tian et al. 2009; He et al. 2010; Wang et al. 2010). Though various reports have demonstrated that the cytotoxicity induced by SDT might be triggered in multiple ways, the exact linkages between specific signal transduction pathways and their activation process remain unclear. It has been proven 
by studies that MAPK (mitogen-activated protein kinase) signal pathways, members of the serine/threonine kinase family, including c-Jun NH2-terminal kinase (JNK), extracellular signal-regulated kinase (ERK), and p38 MAPK, are usually responsible for ROS-mediated cell apoptosis (Matsuzawa et al. 2005; El-Najjar et al. 2010). Many investigations have supported the general view that the activation of ERK pathway delivers a survival signal which counteracts the pro-apoptotic effect associated with JNK and p38 activation (Chen et al. 1996; Graves et al. 1996; Guyton et al. 1996; Wang et al. 1998).

In our paper, we found that the ERK was also activated accompanied by p38 MAPK and JNK activation, while the ERK inhibitor U0126 significantly enhanced SDT-induced human leukemia U937 cell viability loss. The survival mechanisms of ERK activity are less well described and appear to be cell type- and system-specific. Therefore, the purpose of the present study was to elucidate the roles of the ERK on
SDT-induced death of human leukemia U937 cells by using ERK inhibitor U0126. The findings may provide some information for clinical leukemia therapy.

\section{Materials and Methods}

\section{Chemicals}

Chlorin-e6 (Ce6) was purchased from Sigma Chemical company (St Louis, MO, USA) and was dissolved in 0.01 M PBS (pH 7.2), sterilized, aliquoted and stored in the dark at $-20^{\circ} \mathrm{C}$. Rhodamine-123 (Rh123), 4'-6-diamidino2-phenylindole (DAPI), propidium iodide (PI) and the specific ERK inhibitor U0126 were purchased from Sigma Chemical Company. 2', 7'- dichlorodihydrofluoresceindiacetate (DCFH-DA) was supplied by Molecular Probes
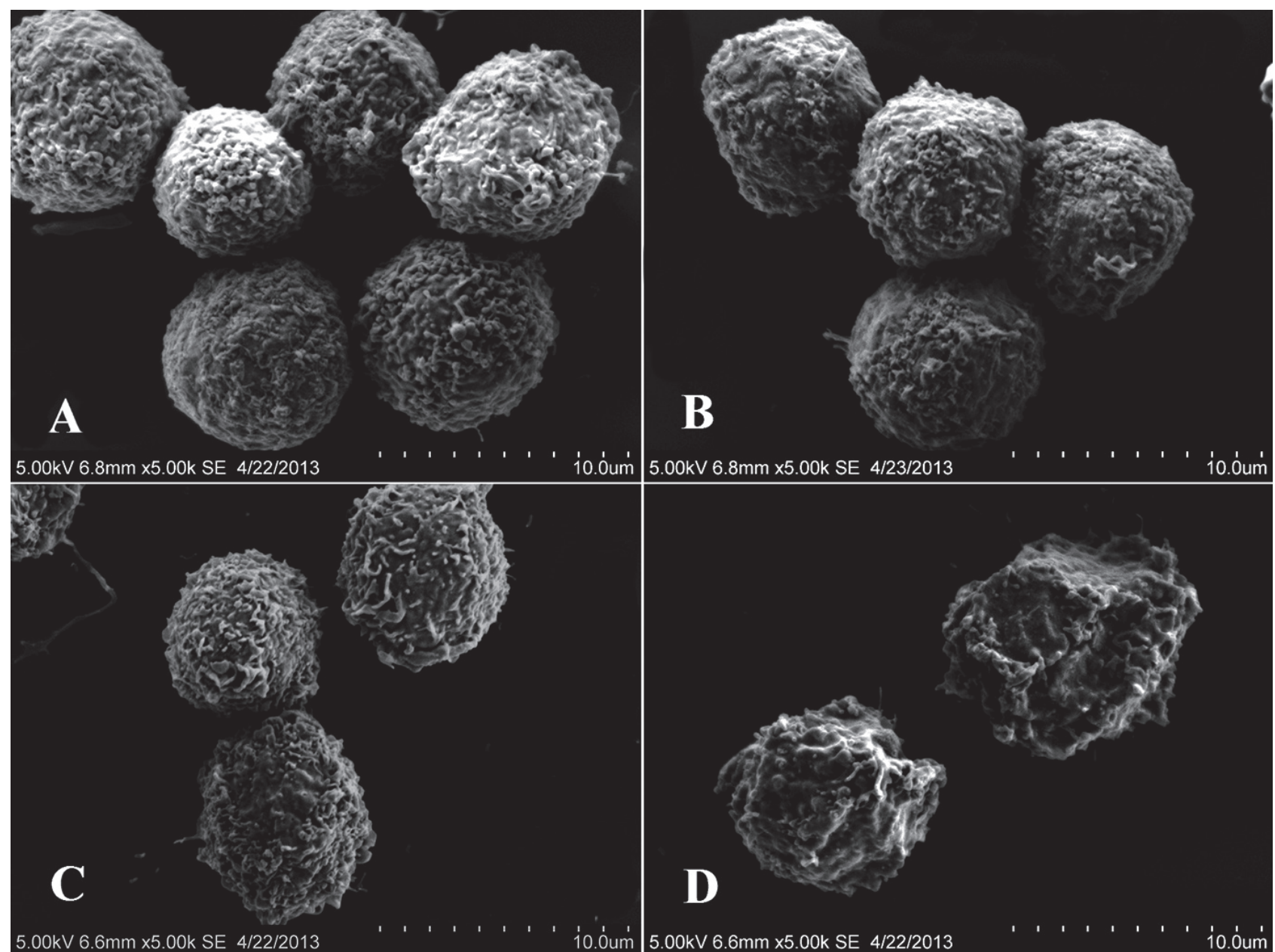

Figure 1. Scanning electron microscopic observation of U937 cells after different treatment $(\times 5000)$. A. Control group with untreated cells. B. Cells treated with $10 \mu \mathrm{g} / \mathrm{ml} \mathrm{Ce} 6$ alone. C. Cells irradiated with $1 \mathrm{~W} / \mathrm{cm}^{2}$ ultrasound alone. D. Cells irradiated with $1 \mathrm{~W} / \mathrm{cm}^{2}$ ultrasound in the presence of $10 \mu \mathrm{g} / \mathrm{ml} \mathrm{Ce} 6$. (Scale bar: $10 \mu \mathrm{m}$ ). 
Inc/Invitrogen (Eugene, OR, USA). Guava ViaCount Assay kit (4000-0040) and Guava Nexin Assay kit (4500-0450) were obtained from Guava technologies Inc. (Hayward, CA, USA). Antibodies against phospho-JNK, phospho-p38 MAPK, phosphor-ERK1/2, ERK1/2 were obtained from Cell Signaling Technology (Beverly, MA, USA). Caspase 3 antibody was acquired from Santa Cruz Biotechnology (Santa Cruz, CA, USA). Anti-GAPDH monoclonal antibody was supplied by EarthOX company (San Francisco, CA, USA).

\section{Cell culture}

Human acute myeloid leukemic cell line U937 was obtained from Institute of Chinese Academy of Medical Sciences (Beijing, China). The cell line was cultured in RPMI 1640 medium supplemented with $10 \%$ heat-inactivated fetal bovine serum, $100 \mathrm{U} / \mathrm{ml}$ penicillin, $100 \mu \mathrm{g} / \mathrm{ml}$ streptomycin and $1 \mathrm{mM}$ L-glutamine. The cells were passaged 1-2 days. Cells were maintained at $37^{\circ} \mathrm{C}$ in humidified $5 \% \mathrm{CO}_{2}$ atmosphere.
Cells in the exponential phase of growth were used in each experiment.

\section{Ultrasound exposure setup}

The experiment set-up for insonation was the same as previously described (Su et al. 2013). Briefly, the focused ultrasound transducer with a circular ceramic plate of $15 \mathrm{~mm}$ in diameter, manufactured by the Institution of Applied Acoustics, Shaanxi Normal University (Xian, Shaanxi, China), was submerged in degassed water in the tank facing directly upward. The electrical signal was generated and amplified by a multi-functional generator (AG1020, T\&C Power Conversion, Inc, Rochester, NY, USA) before feeding the transducer. The ultrasound field distribution was recorded by the Ultrasonics C-Scan image System (3560C, Physical acoustics corporation, USA). The central focal spot was shown at about $26 \mathrm{~mm}$ away from the piezoelectric sound source. The produced focus area was about 6-8 $\mathrm{mm}$ in width, and the depth of focus was about $1.6 \mathrm{~cm}$. Ultrasound irradiation was conducted with a frequency of
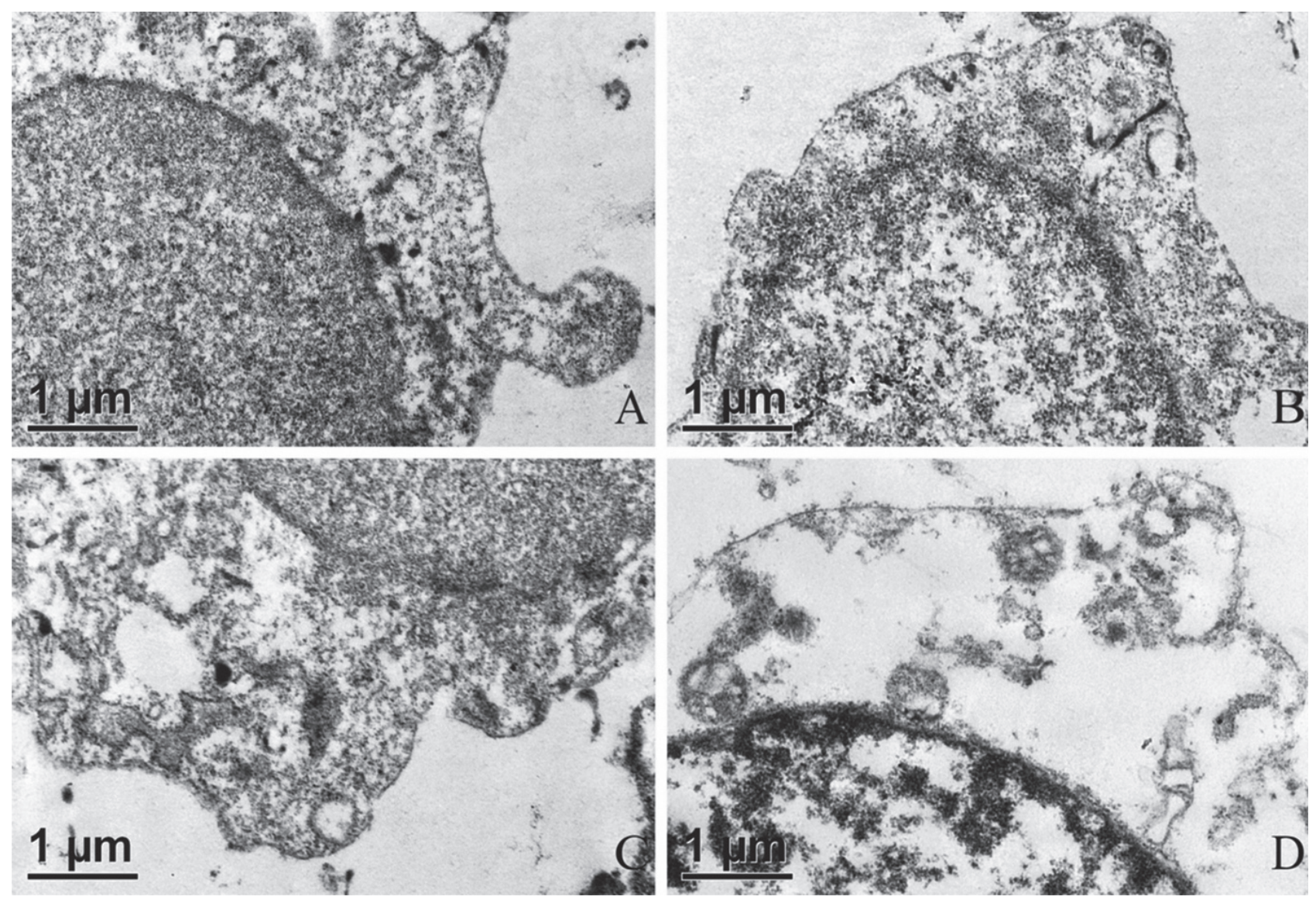

Figure 2. Transmission electron microscopic observation of U937 cells after different treatment $(\times 10000)$. A. Control group with untreated cell. B. Cells treated with $10 \mu \mathrm{g} / \mathrm{ml} \mathrm{Ce} 6$ alone. C. Cells irradiated with $1 \mathrm{~W} / \mathrm{cm}^{2}$ ultrasound alone. D. Cells irradiated with $1 \mathrm{~W} / \mathrm{cm}^{2}$ ultrasound in the presence of $10 \mu \mathrm{g} / \mathrm{ml} \mathrm{Ce6}$. (Scale bar: $1 \mu \mathrm{m}$ ). 
1.1 $\mathrm{MHz}$ in a continuous wave mode for $60 \mathrm{~s}$ duration. The sample $(0.5 \mathrm{ml})$ contained in a polypropylene test tube was placed into the center of the focal zone for irradiation. Samples were submerged entirely in degassed water and the test tube was rotated at $20 \mathrm{rpm}$ by a micro-motor to improve mixing and to provide a uniform exposure. In 1640 serum-free medium, in the free-field conditions, we previously evaluated that the acoustic intensities in the tube were about $1 \mathrm{~W} / \mathrm{cm}^{2}$ (ISATA, spatial average time average intensity) when the load power by the AG1020 apparatus indicated $3 \mathrm{~W}$, which was used throughout the experiment.

For all experiments, the coupling water was degassed before ultrasound treatment and was maintained at room temperature during irradiation. Temperature increase inside the test tube was measured before and after ultrasound treatment with a digital thermometer, and no significant variation of temperature was detected $\left( \pm 1^{\circ} \mathrm{C}\right)$. Thus, any bio-effects observed in this study were considered to be non-thermal.

\section{SDT treatment protocols}

U937 cells in the exponential phase were collected and divided randomly into four groups: control, Ce6 alone, ultrasound alone, and ultrasound+Ce6. For Ce6 and ultrasound+Ce6 groups, the cells were incubated with $10 \mu \mathrm{g} / \mathrm{ml} \mathrm{Ce} 6$ involved a $4 \mathrm{~h}$ drug-loading time in serum-free RPMI 1640 medium, allowing sufficient time for cell uptake of the sensitizer to reach a relatively high level. Instead of $\mathrm{Ce} 6$, an equivalent quantity of PBS was used for the control and ultrasound alone groups. The cells in ultrasound and ultrasound+Ce6 groups were exposed to ultrasound at a frequency of $1.1 \mathrm{MHz}$ and an intensity of $1 \mathrm{~W} / \mathrm{cm}^{2}$ for $60 \mathrm{~s}$ duration. After the treatment procedure, cells were re-suspended in fresh medium and cultured for an additional time as specified in the text and then subjected to different analysis.

For inhibitory studies, ERK inhibitor U0126 (10 $\mu \mathrm{M})$ was added to culture medium prior to loading Ce6 $1 \mathrm{~h}$.
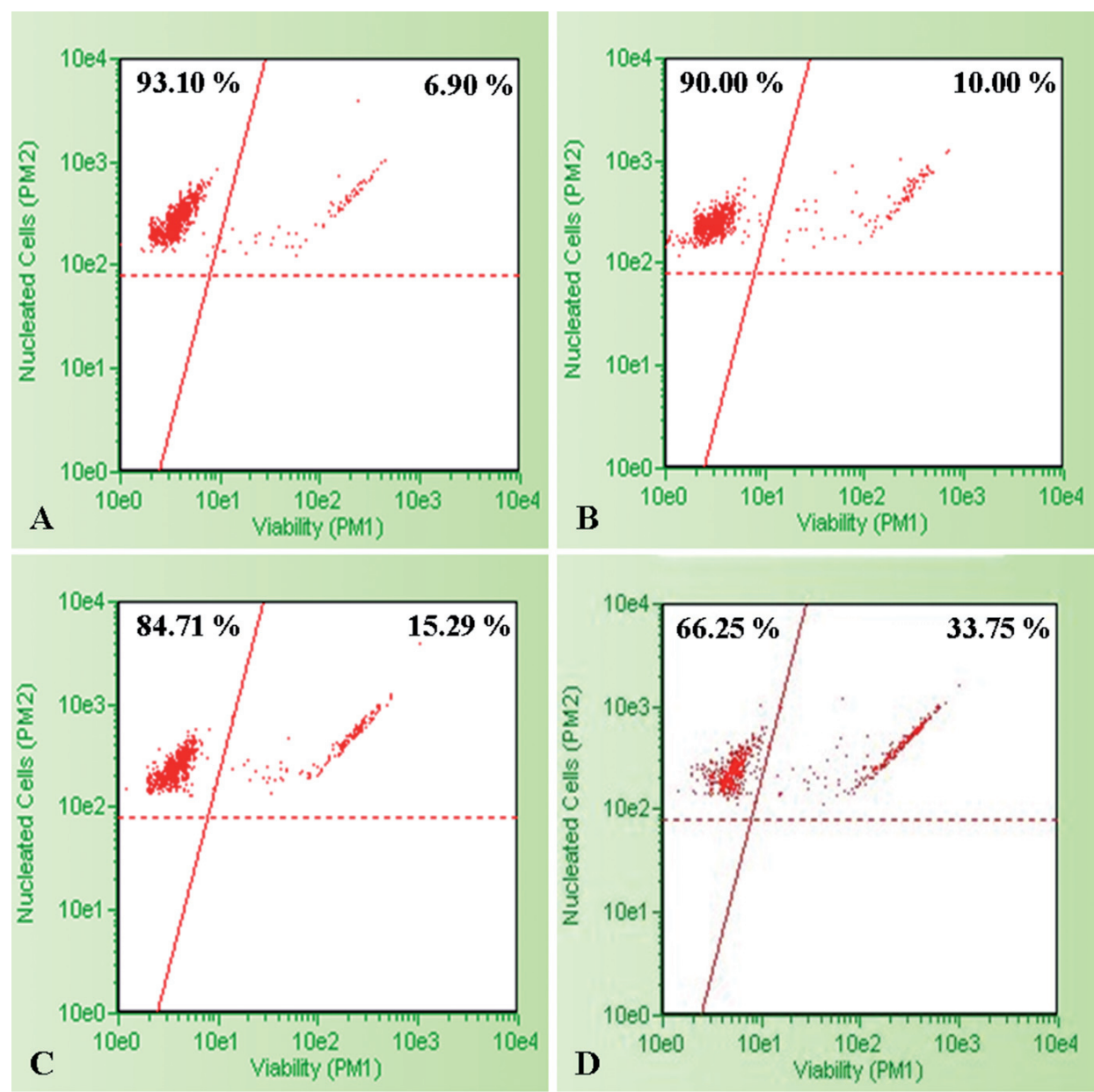

Figure 3. The viability of U937 cells at $0.5 \mathrm{~h}$ after Ce6-SDT was assessed by ViaCount viability assay. A. Control group with untreated cell. B. Cells treated with $10 \mu \mathrm{g} / \mathrm{ml}$ Ce6 alone. C. Cells irradiated with $1 \mathrm{~W} / \mathrm{cm}^{2}$ ultrasound alone. D. Cells irradiated with $1 \mathrm{~W} / \mathrm{cm}^{2}$ ultrasound in the presence of $10 \mu \mathrm{g} / \mathrm{ml} \mathrm{Ce6}$. The data indicate mean \pm SD from four different experiments. Six replicates in each one experiment. 
A

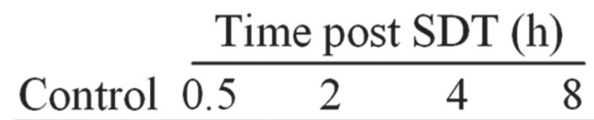

Phospho-p38
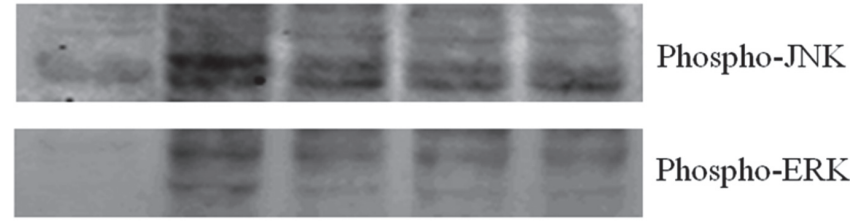

Figure 4. A. Expression changes of MAPK related proteins by immunoblot analysis at different times after Ce6-SDT treatment. GAPDH was used as a loading control. B. Data are evaluated in the graph. Control, cells without any treatment; SDT, cells were irradiated with $1 \mathrm{~W} / \mathrm{cm}^{2}$ ultrasound in the presence of $10 \mu \mathrm{g} / \mathrm{ml} \mathrm{Ce} 6$. Data are means \pm SD from four independent experiments. ${ }^{\star} \mathrm{p}<0.05$, ${ }^{* *} p<0.01$ compared with control group.

\section{B}
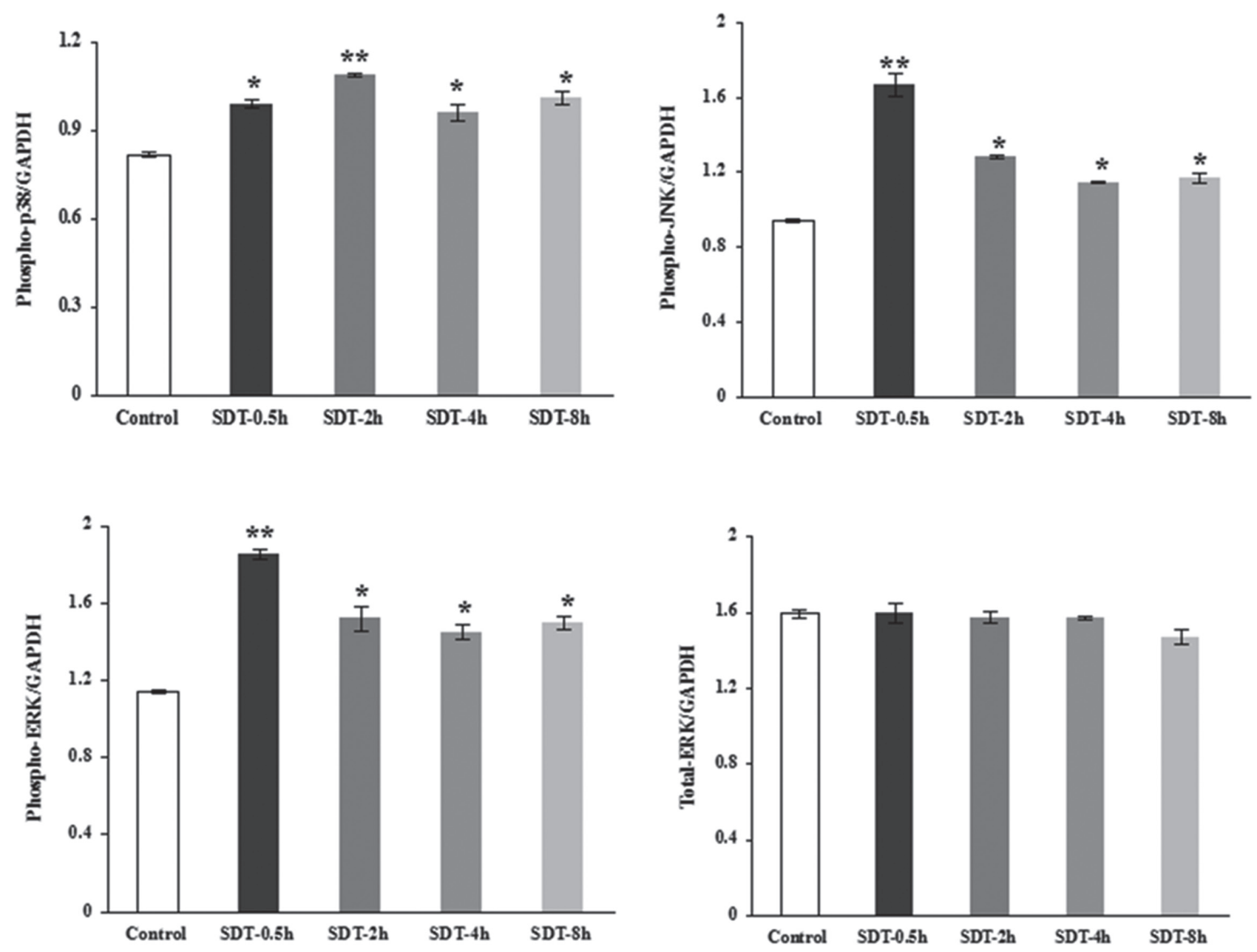
This inhibitor at the used concentration did not yield any significant cell damage to cultured cells.

\section{Scanning electron microscope (SEM) observation}

Immediately after ultrasound treatment, cells were fixed in $2.5 \%$ glutaraldehyde for $1 \mathrm{~h}$ at $4^{\circ} \mathrm{C}$, washed by PBS ( 3 times, $10 \mathrm{~min} /$ times), then stained in $1 \%$ osmium tetraoxide for $1 \mathrm{~h}$ at $4^{\circ} \mathrm{C}$, washed by PBS ( 3 times, $10 \mathrm{~min} /$ times), dehydrated by gradient alcohol, displaced in isoamyl acetate, dried at the critical point, gold evaporated, and observed using a scanning electron microscope (Quanta 200, PhilipsFEI Company, Hillsboro, USA).

\section{Transmission electron microscope (TEM) observation}

The tumor cells were collected immediately after SDT treatments, and then fixed in $2.5 \%$ glutaraldehyde for $1 \mathrm{~h}$ at $4^{\circ} \mathrm{C}$, followed by post-fixation for $1 \mathrm{~h}$ at $4^{\circ} \mathrm{C}$ in $1 \%$ osmium tetroxide $\left(\mathrm{OsO}_{4}\right)$. After washing by PBS, the samples were dehydrated by graded alcohol, embedded with Epon 812 and ultrathin sectioned. The sections were stained with uranium acetate and lead citrate, and examined under a transmission electron microscope (H-600, Hitachi, Tokyo, Japan).

\section{Cell viability assay}

The cell viability was determined by the ViaCount viability assay. At $0.5 \mathrm{~h}$ after ultrasound exposure, cells in $25 \mu \mathrm{l}$ were added to 96 well culture plates, and viability was determined by adding $225 \mu \mathrm{l}$ ViaCount reagent to each well, and the mixture was then incubated at room temperature for $5 \mathrm{~min}$. Guava flow cytometry system with CytoSoft software containing the ViaCount module was used for sample acquisition and analysis (Guava easyCyte 8HT, Millipore, Boston, MA, USA).

\section{Western blotting analysis}

SDS-PAGE and immunoblotting were performed according to standard procedures. Briefly, cells were lysed by RIPA buffer on ice. The protein samples were separated on a $10-15 \%$ SDS polyacrylamide gel, and then the gel was transferred to nitrocellulose membranes (Millipore, MA, USA) and blotted with primary antibodies overnight at $4^{\circ} \mathrm{C}$. The bound primary antibodies were then tagged with IRDye 680 Conjugated IgG (Li-cor, Biosciences, Lincoln, $\mathrm{NE}, \mathrm{USA}$ ) at room temperature for $1 \mathrm{~h}$. And the infrared fluorescence was detected with the Odyssey infrared imaging system (Li-Cor Bioscience, Lincoln, NE, USA).
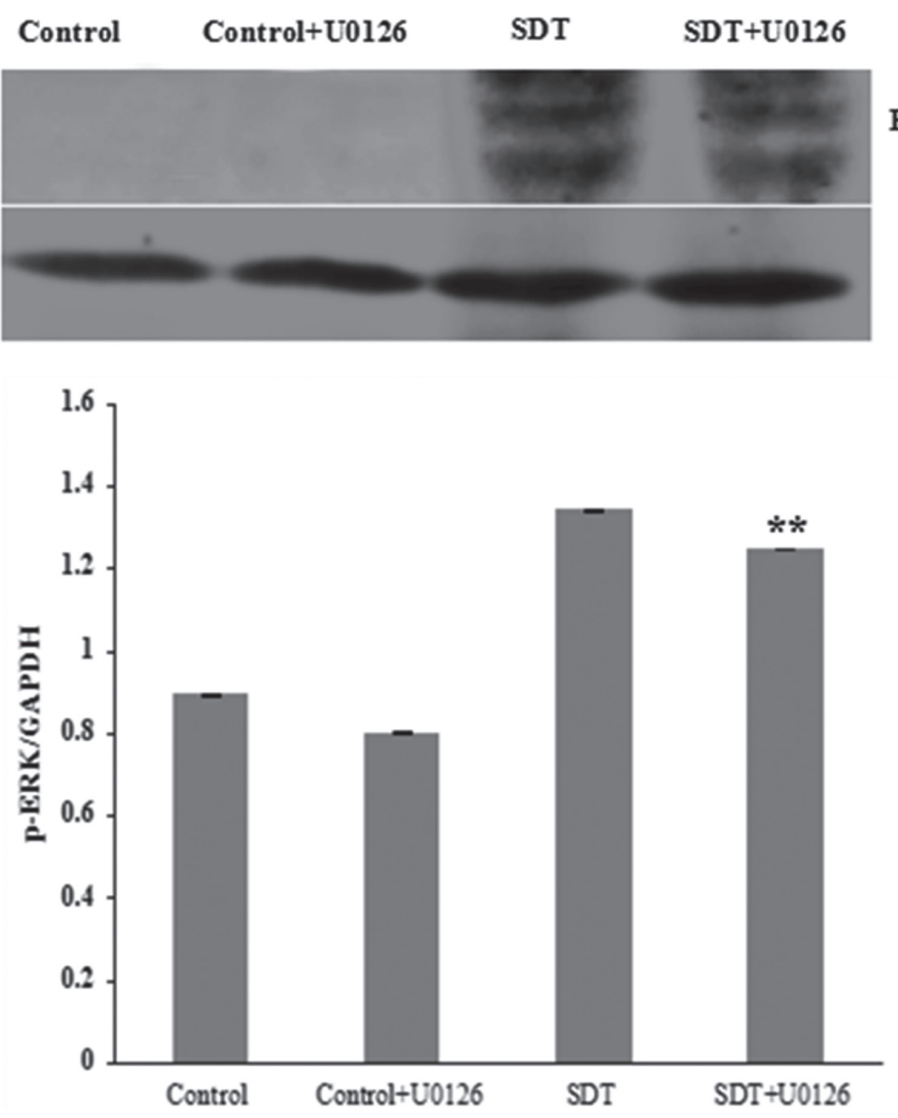

\section{Phospho-ERK}

\section{GAPDH}

Figure 5. Western blotting analysis of the activation of ERK in U937 cells after $0.5 \mathrm{~h}$ incubation following SDT treatment with or without U0126. Control, cells without any treatment; Control+U0126, cells with $10 \mu \mathrm{mol} / \mathrm{l} \mathrm{U} 0126$ alone; SDT, cells were irradiated with $1 \mathrm{~W} /$ $\mathrm{cm}^{2}$ ultrasound in the presence of $10 \mu \mathrm{g} / \mathrm{ml}$ Ce6; SDT+U0126, cells were irradiated with $1 \mathrm{~W} / \mathrm{cm}^{2}$ ultrasound in the presence of $10 \mu \mathrm{g} /$ ml Ce6 with U0126 pre-treatment. Data are presented as mean $\pm \mathrm{SD}$ of four independent assessments. ${ }^{* *} p<0.01$ versus SDT. 


\section{ERK inhibitor studies}

Cell viability evaluation

To evaluate the role of ERK in SDT-induced cytotoxic effects in U937 cells, the cells were treated with $10 \mu \mathrm{M}$ U0126 prior to SDT treatment. At $0.5 \mathrm{~h}$ post treatment, the cell viability was evaluated by ViaCount assay.

Apoptosis detection by flow cytometry

In the present study, after $2 \mathrm{~h}$ of incubation post SDT, early cell apoptosis was analyzed using a flow cytometer with An-
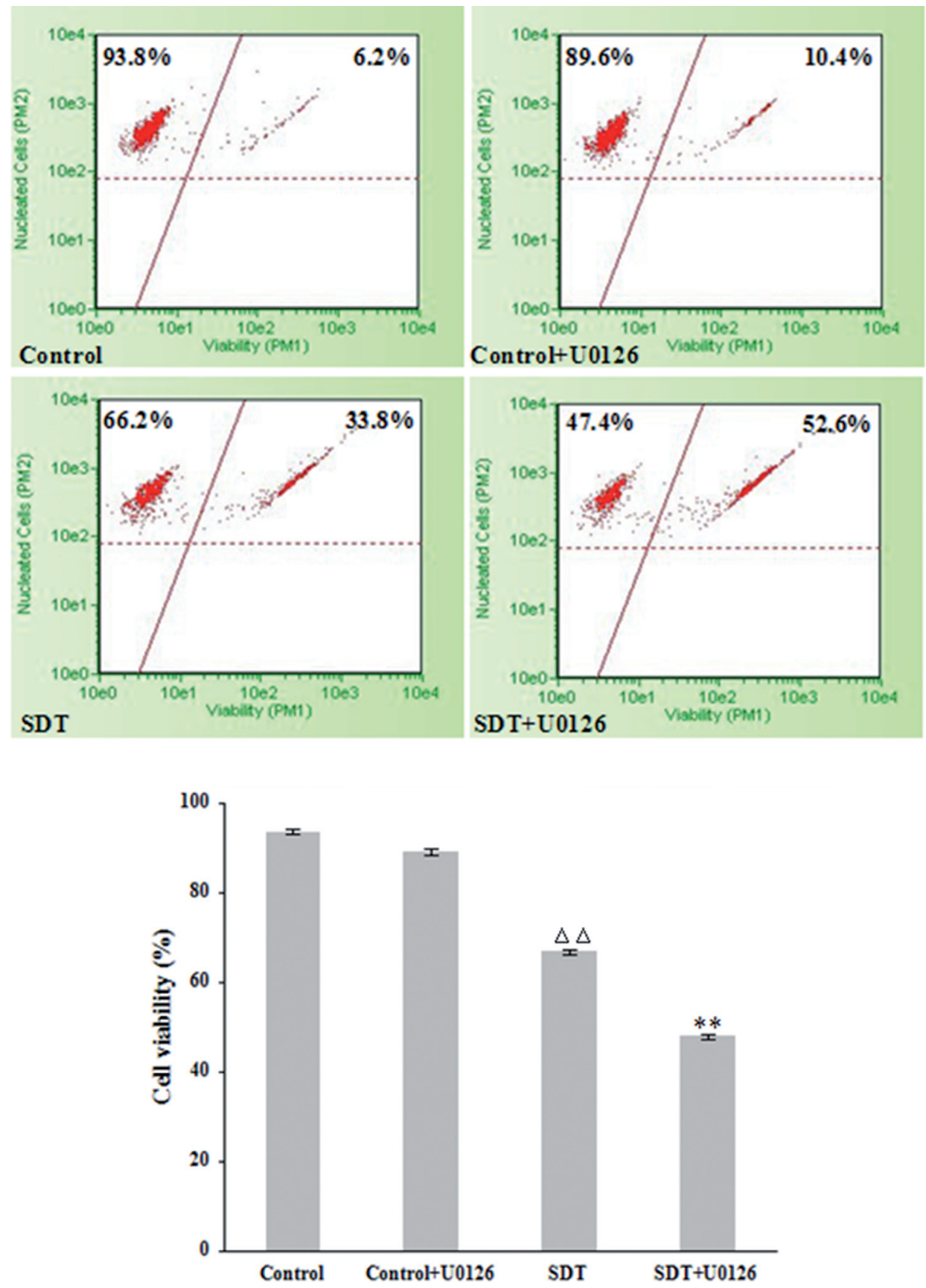

Figure 6. Effect of different ERK inhibitors on SDT induced cytotoxicity. The data indicate mean \pm SD from four different experiments. Six replicates in each one experiment. ${ }^{\Delta \Delta} p<0.01$ versus untreated controls; ${ }^{* *} p<0.01$ versus SDT. (For abbreviations, see Figure 5). 
nexin V-PE and 7-AAD staining. Briefly, $100 \mu \mathrm{l}$ cells from each sample were suspended in a mixture of $100 \mu \mathrm{l}$ Annexin $\mathrm{V}-\mathrm{PE}$ and 7-ADD binding buffer and then incubated at room temperature for $20 \mathrm{~min}$. The samples were analyzed using a flow cytometry (Guava easyCyte 8HT, Millipore, Boston, MA, USA). The population was separated into three groups: live cells with a low level of fluorescence; apoptotic cells in the earlier period with green fluorescence; and the advanced stage apoptotic cells with both red and green fluorescence.

\section{DAPI staining}

U937 cells were incubated for $24 \mathrm{~h}$ post SDT, then washed with PBS and stained with $4 \mu \mathrm{g} / \mathrm{ml}$ DAPI for $30 \mathrm{~min}$ at $37^{\circ} \mathrm{C}$. After washing with PBS, cells were observed under a fluorescence microscopy (Nikon E-600, Tokyo, Japan).

\section{DNA fragmentation analysis}

An easy and quantitative way to analyze DNA fragmentation based on flow fluorocytometric detection of DNA hypoploidy after adding PI to the dying cells and permeabilizing them by freeze-thawing was described in Krysko et al. (2008). To investigate the effect of ERK inhibitor U0126 on SDT induced DNA damage of U937 cells, we performed oligonucleosomal DNA fragmentation by flow fluorocytometry. At $24 \mathrm{~h}$ post treatment, U937 cells were stained with $5 \mu \mathrm{g} / \mathrm{ml} \mathrm{PI}$ and analyzed for DNA content by using flow cytometry.

\section{Determination of intracellular ROS and the mitochondria membrane potential (MMP)}

Intracellular ROS was analyzed using a flow cytometer with DCFH-DA. DCFH-DA, a non-fluorescent dye, can freely permeate cells. Once inside the cells, DCFH-DA is hydrolyzed to DCF by endogenous esterases and entrapped intracellularly. Then, DCF interacts with intracellular ROS and converts it to fluorescent compound which could be readily detected. To estimate intracellular ROS, immediately after treatment, both the control and treated cells were loaded with $100 \mathrm{nM} \mathrm{DCFH-DA}$ for $10 \mathrm{~min}$ at $37^{\circ} \mathrm{C}$, washed with PBS and immediately analyzed using flow cytometry.

Rh123 was used to evaluate perturbations in MMP (mitochondria membrane potential) of U937 cells. Once the MMP is lost, Rh123 is subsequently washed out of the cells.
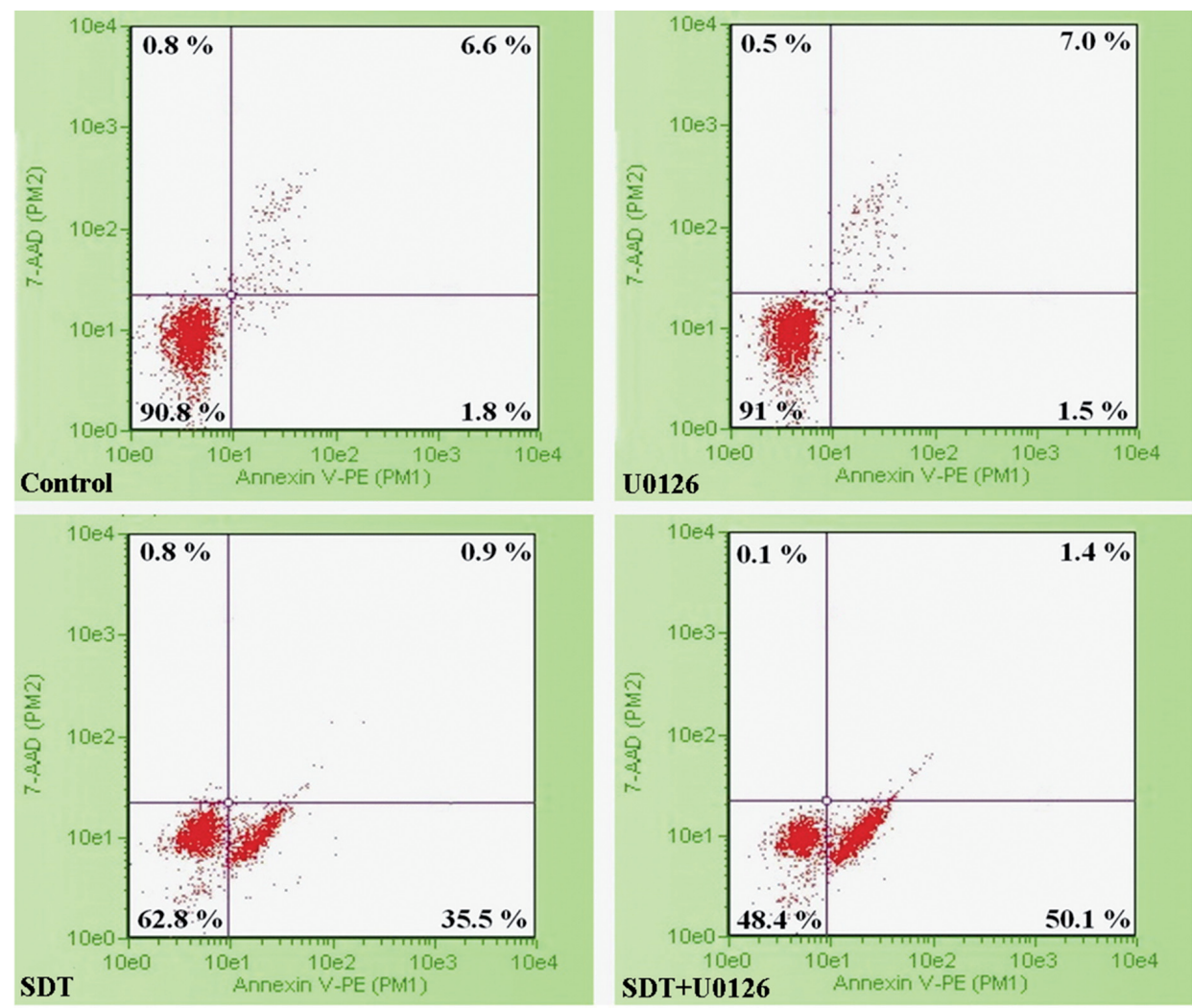

Figure 7. Effects of ERK inhibitor U0126 on cell apoptosis of U937 cells. The cells were double stained with Annexin V-PE and 7-AAD as described in the methods after $2 \mathrm{~h}$ incubation following SDT with or without U0126 pre-treatment. (For abbreviations, see Figure 5). 
At $1 \mathrm{~h}$ post-treatment, cells were stained with $2 \mu \mathrm{g} / \mathrm{ml} \mathrm{Rh} 123$ in an incubator for 20 min with gentle shaking, followed by washing with PBS; after that, the samples were immediately analyzed using flow cytometry.

\section{Statistical analysis}

All values were expressed as means \pm SD of at least three independent experiments, the differences among the groups were analyzed by one-way ANOVA test.

\section{Results}

\section{SEM observation}

SEM observation of the surface of U937 cells after $60 \mathrm{~s}$ exposure at an ultrasonic intensity of $1 \mathrm{~W} / \mathrm{cm}^{2}$ in the presence and absence $10 \mu \mathrm{g} / \mathrm{ml} \mathrm{Ce} 6$ is shown in Figure 1. The control group showed untreated cells with numerous microvilli over the cell surface (Fig. 1A); Ce6 alone and ultrasound alone had only a slight effect on the surface of the cells, and had no significant difference with control group (Fig. 1B and C). While cells exposed to identical ultrasound conditions in the presence of $10 \mu \mathrm{g} / \mathrm{ml} \mathrm{Ce} 6$ were seriously damaged with apparent deformation (Fig. 1D), some papillous protuberances were seen in the surface of cells where the cytoplasm seemed to have extruded through the membrane boundary.

\section{TEM observation}

TEM observation of U937 cells immediately after SDT treatment is shown in Figure 2. The cells in control group were intact with rich cytoplasm, cell membranes and nuclear envelope were intact, nuclear materials were dense (Fig. 2A). The morphology of cells in Ce6 group was similar to that
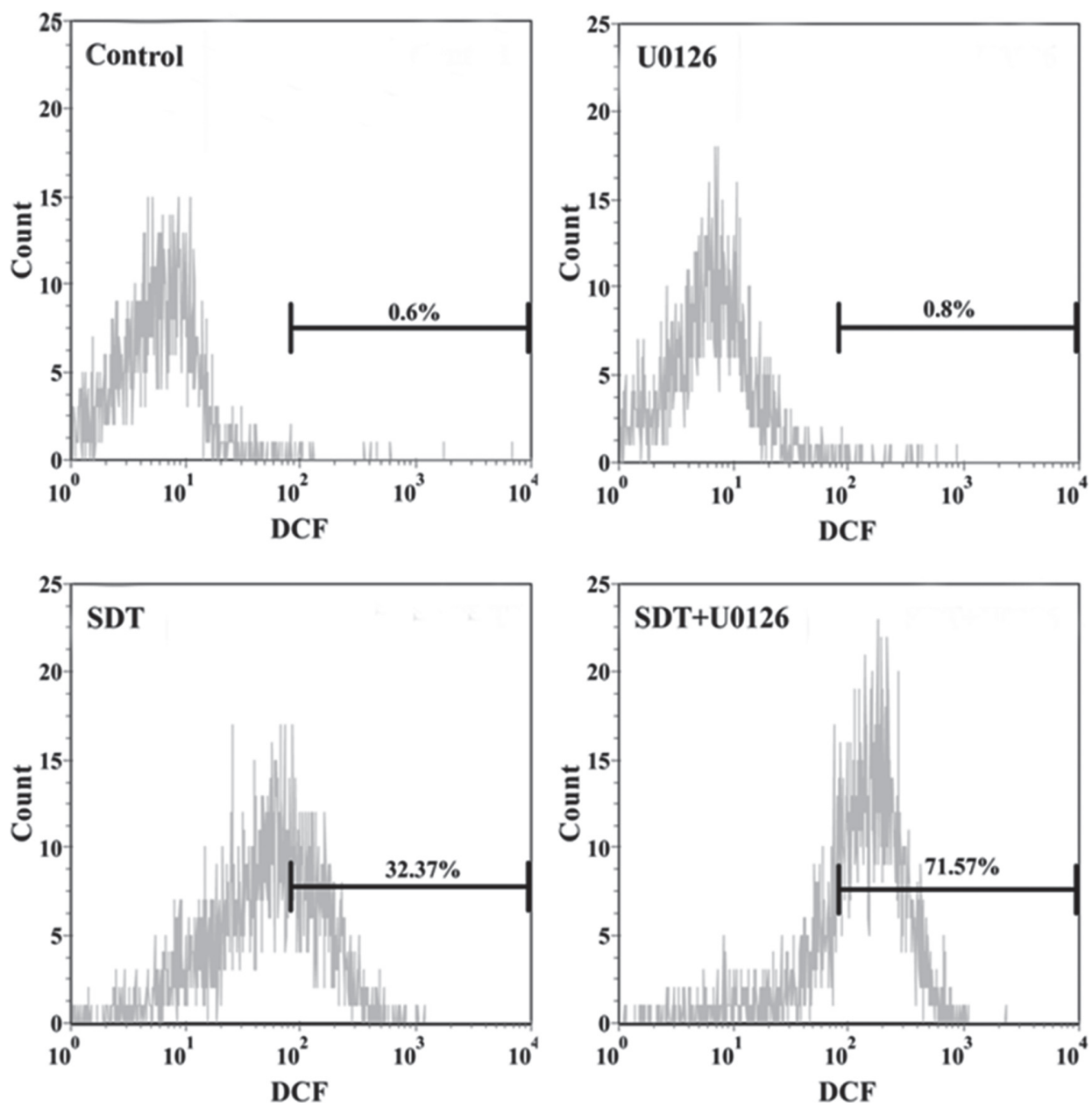

Figure 8. Measurement of intracellular ROS in U937 cells. The cells were labeled with DCFH-DA, the fluorescence intensity of DCF in the cells was detected by flow cytometry. (For abbreviations, see Figure 5). 
in control group, cell membranes were still intact with rich cytoplasm (Fig. 2B). Cells in ultrasound group, showed a few small bubbles appeared in the less dense cytoplasm in some cells (Fig. 2C). The cell morphology was changed greatly in ultrasound+Ce6 group. In most cells, organelles in the cytoplasm were sparse, some materials in cytoplasm were lost, and chromatin in nuclear were greatly condensed (Fig. 2D).

\section{Cytotoxicity of Ce6-SDT on U937 cells}

The treated cells were incubated for $0.5 \mathrm{~h}$ to assess the cytotoxicity of Ce6-mediated SDT (Ce6-SDT) on U937 cells. The data in Figure 3 revealed that, compared with control (93.10\%), there were not significant cytotoxicity in Ce6 alone and ultrasound alone groups, and their cell viability were about $90 \%$ and $84.7 \%$, respectively. While the synergistic effect of ultrasound+Ce6 showed significant cell killing, which caused $33.75 \%$ cell viability loss. This combined cytotoxicity of Ce6-SDT was much higher than that of Ce6 or ultrasound alone $(p<0.01)$.
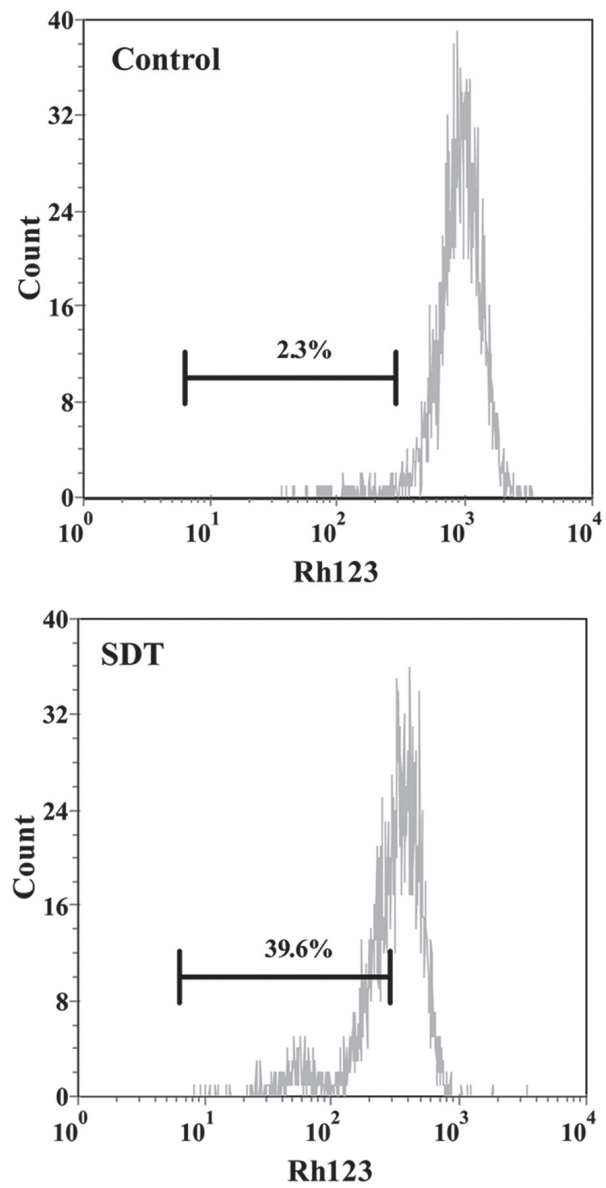

Analysis of activation of MAPK

Next, we investigated the effect of SDT treatment on the activities of MAPK to determine if these signaling pathways were involved in the observed apoptotic response. Some key MAPK related protein changes in U937 cells were detected by Western blotting. As shown in Figure 4A and B, p38 phosphorylation was visibly increased in U937 cell at $0.5 \mathrm{~h}$ post ultrasound+Ce6, peaked at $2 \mathrm{~h}$ and then sustained at a higher level within $8 \mathrm{~h}(p<0.01)$. JNK was also significantly phosphorylated at $0.5 \mathrm{~h}$ post ultrasound $+\mathrm{Ce} 6(p<0.01)$. In ERK pathway, the phosphorylation of ERK1/2 was also detected at the early stage of ultrasound+Ce6, which quickly declined with the increased incubation time $(p<0.01)$. The total ERK1/2 didn't change any more after treatment.

\section{ERK inhibitor studies}

ERK pathway is reported to be closely associated with cell survival (Wang et al. 1998), so in the present study we meas-
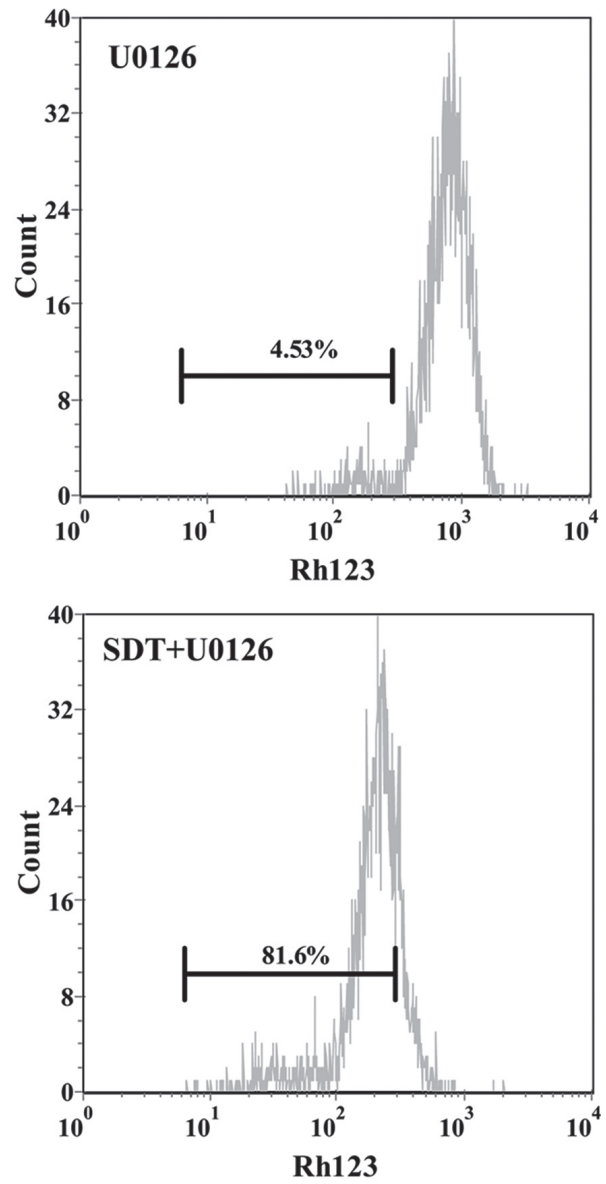

Figure 9. Measurement of intracellular MMP in U937 cell. The cells were labeled with Rh123, fluorescence intensity in the cells was detected by flow cytometry. (For abbreviations, see Figure 5). 
ured the ERK related factors. Our preliminary data showed that SDT could activate ERK in U937 cells. Furthermore, when detecting the activation of ERK in the presence of ERK pharmacological inhibitor U0126, we found that U0126 suppressed the SDT-induced phosphorylation of ERK1/2 (Fig. 5). Therefore we are next interested to further explore the potential role of ERK in cytotoxic effect of U937 cells by using U0126. As shown in Figure 6, the SDT-induced U937 cell viability loss was significantly enhanced by pre-treatment with $10 \mu \mathrm{M}$ U0126 $(p<0.01)$, indicating the activation of ERK after SDT treatment might regulate U937 cell survival. $10 \mu \mathrm{M}$ U0126 alone did not affect the cell viability of control. In addition, the SDT-induced cell apoptosis, ROS generation, MMP loss, chromatin condensation, DNA fragmentation and caspase- 3 activation were all differently enhanced by pre-treatment with U0126 (Fig. 7-12). These results suggested ERK signal pathway might deliver a survival signal that protected SDT-induced cell death and apoptosis in U937 cells, which also pointed out that the combination of SDT with ERK inhibitor U0126 could significantly enhance SDT-induced cytotoxicity.

\section{Discussion}

SDT-caused cell damage has been studied under different ultrasonic parameter settings by using various sonosen- sitizers and cell lines. The mechanisms are discussed by detecting the changes in cell structure, oxidase activity, mitochondria swelling, chromatin condensation and degradation of DNA (Rosenthal et al. 2004; Liu et al. 2006, 2007).

The ultra-structure changes of U937 cell after sonodynamic treatment were evaluated under SEM and TEM. Under SEM, we observed that the ultrasonically-induced cell membrane damage in the present of Ce6 was more serious than that of ultrasound alone group (Fig. 1). Changes on the surface of cell membrane may affect membrane functions, and eventually lead to cell death (Tang et al. 2008). TEM observation in SDT group indicated altered cell membrane, lost of cytoplasm and nucleoplasm, and condensed chromatin (Fig. 2), suggesting that ultrasound irradiation with Ce6 played important roles in the damages of cell membrane system and the inheritance information expression system.

Cell viability rate was assessed by ViaCount viability assay at $0.5 \mathrm{~h}$ after SDT treatment. Data in Figure 3 suggested the ultrasonically-induced cell damage was remarkably aggravated by $10 \mu \mathrm{g} / \mathrm{ml} \mathrm{Ce6}$, whereas Ce6 alone and ultrasound alone did not have significant cytotoxic effect on U937 cells.

Various reports have suggested SDT could induce cell death (Honda et al. 2002; Firestein et al. 2003). The exact mechanisms leading to the cell death, however, are still under
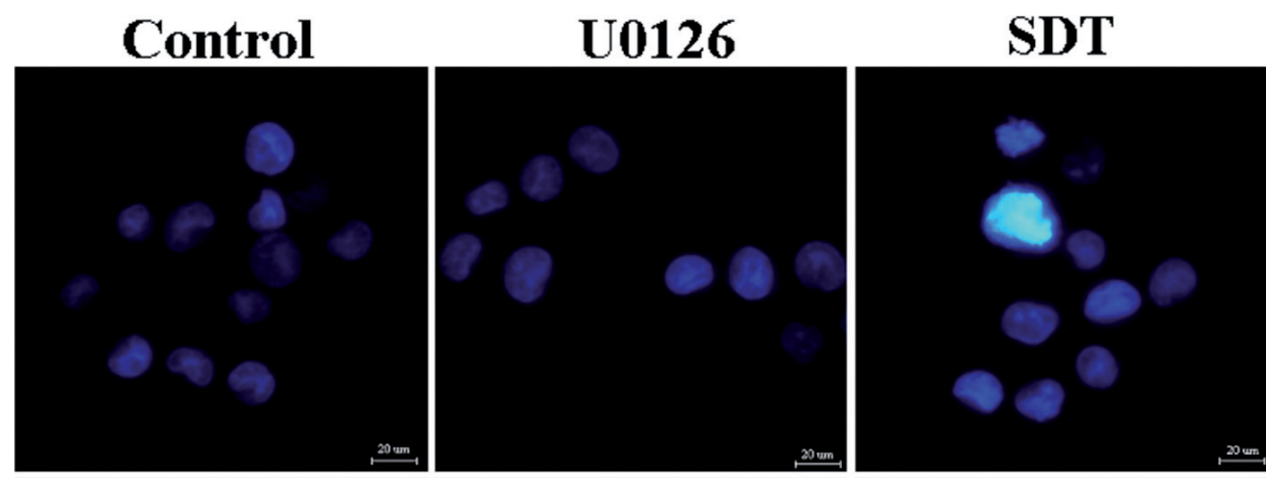

SDT+U0126
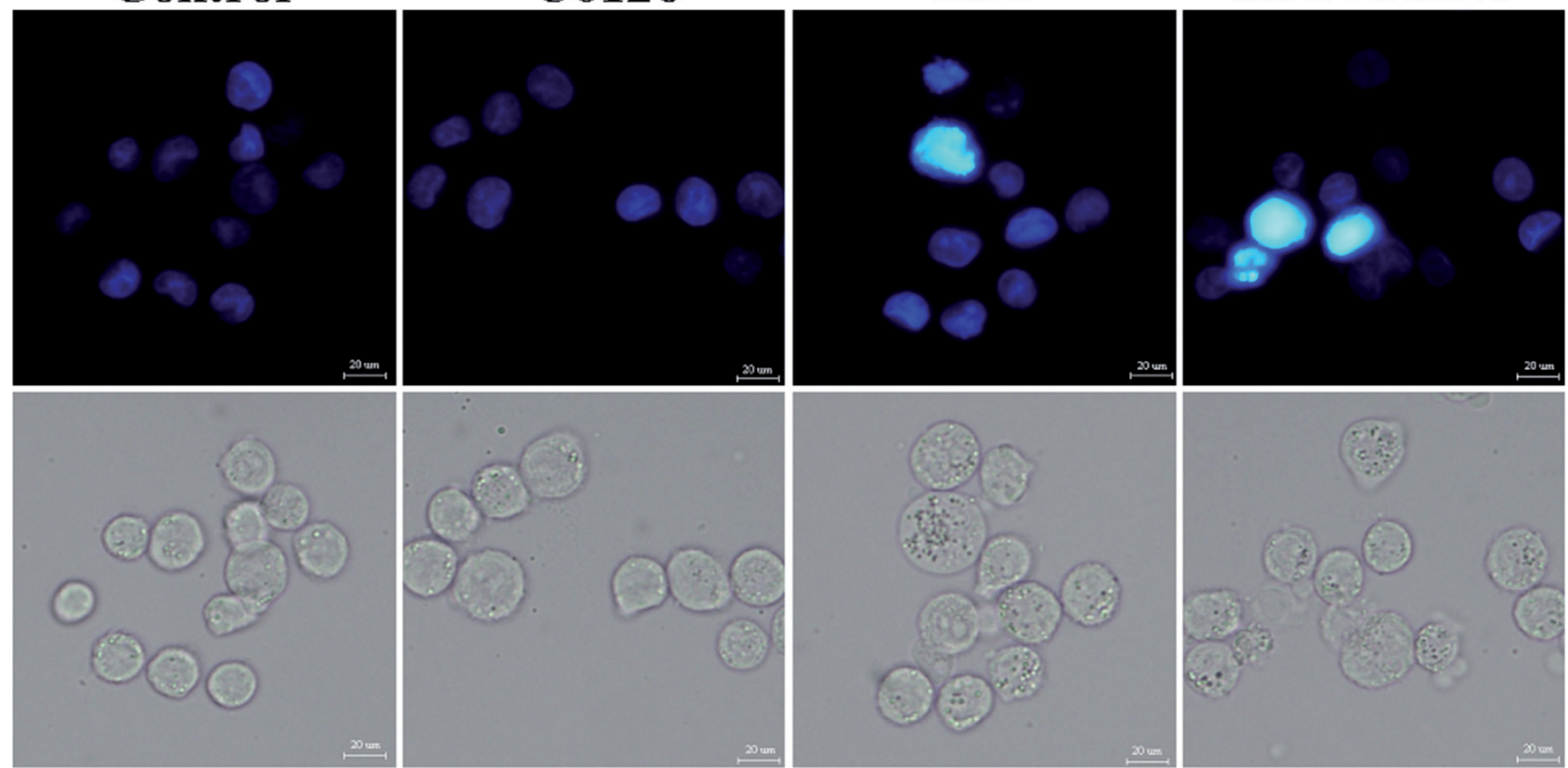

Figure 10. Nuclear DAPI staining in U937 cells after $24 \mathrm{~h}$ incubation following SDT treatment with or without ERK inhibitor U0126 (scale bar: $20 \mu \mathrm{m}$ ). (For abbreviations, see Figure 5). 
investigations. After induction of apoptotic cell death, both pro-apoptotic and anti-apoptotic signaling pathways are activated. Many lines of evidence have demonstrated that the members of MAPK pathway, including p38 MAPK, JNK and ERK, were key factors in cell survival and death (Kang et al. 2000; Zhao et al. 2005; Stanton and Beier 2007). In the present study, we further clarified the roles of MAPKs in Ce6-SDTinduced U937 cell death. The activations of p38 MAPK, JNK and ERK were detected and the different levels of phosphorylation at early period of post ultrasound+Ce6 were observed (Fig. 4A,B). It is well known that the activations of p38 MAPK and JNK pathways may lead to induction of apoptosis through the phosphorylation of a variety of pro-apoptotic downstream effectors, whereas the ERK pathway is often associated with cell survival (Davis 2000; Boutros et al. 2008). To evaluate whether similar event occurred in human leukemia U937 cells when treated by SDT, we applied the common method to study the function of MAPKs by using specific inhibitors. U0126 is one of the most widely used specific MAPK pathway inhibitor, which is an inhibitor of mitogen-activated protein kinase (MEK) acting upstream of Erk1/2, can uncompetitively bind with MEK, inhibit its enzymatic activity and block the downstream phosphorylation of Erk1/2 (Fan et al. 2007). In our paper, data indicated U0126 significantly relieved SDT-induced U937 Erk1/2 activation (Fig. 5). Next, co-treatment with ERK inhibiting agent U0126 caused more serious cytotoxicity (Fig. 6) compared with ultrasound+Ce6 alone. The result showed that ERK signaling pathways might be involved in protecting SDT-induced U937 cytotoxicity. To further verify ERK inhibition indeed enhanced the cytotoxic of U937 cells, cells were pretreated with U0126 for $60 \mathrm{~min}$ before insonation, the proportion of apoptotic cells increased from $36.4 \%$ to $51.5 \%$ after ultrasound+Ce6 and U0126 could additionally aggravate chromatin condensation, DNA damage and caspase-3 activation (Fig. 7, 10, 11, 12). ERK is believed to be a determinant in the activation of the apoptotic program (Luchetti et al. 2009). Monick et al. have clearly showed that ERK inhibition induced cell damage
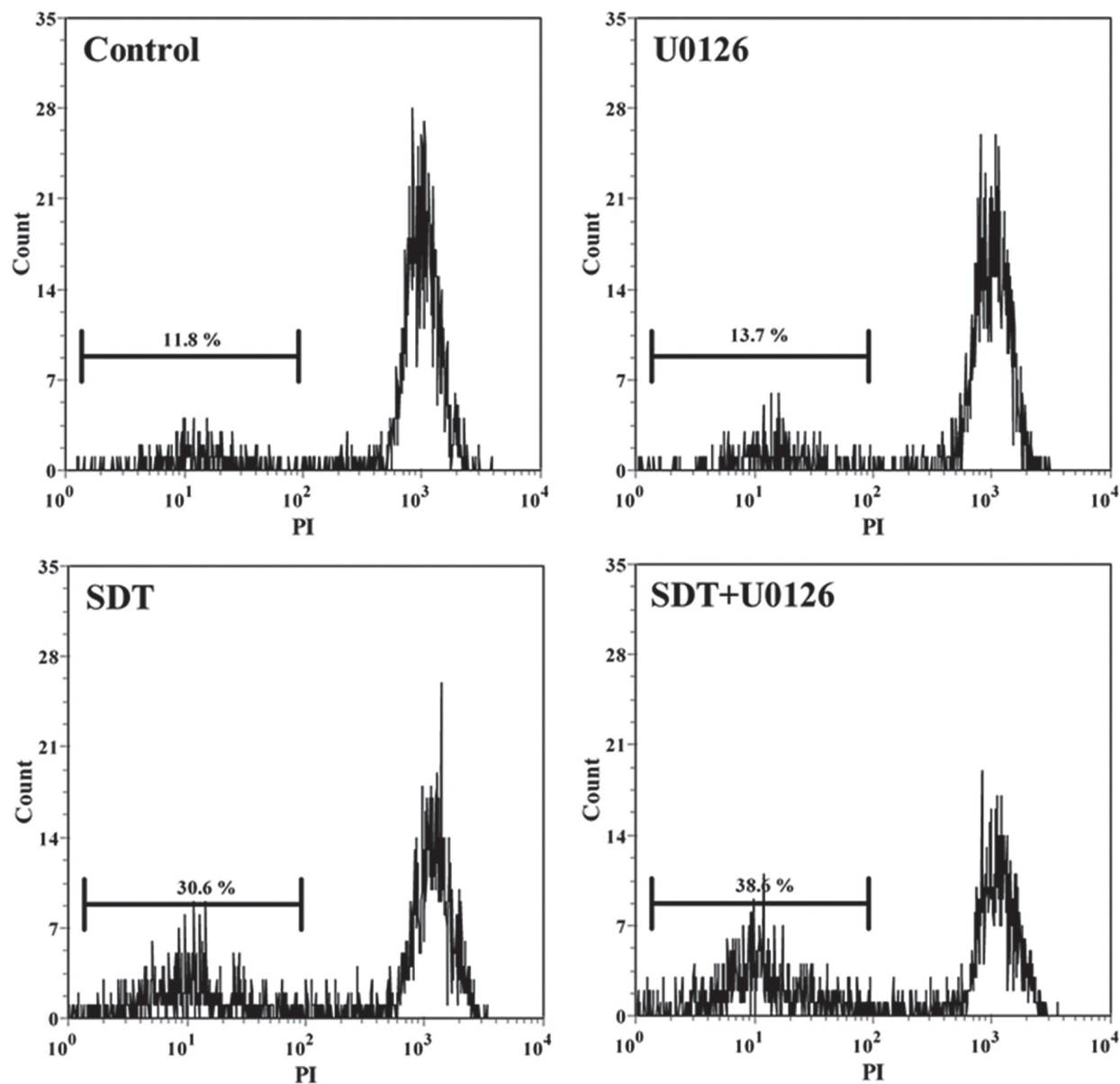

Figure 11. DNA damage analysis by flow cytometry following SDT treatment with or without Erk inhibitor U0126. These data are expressed as mean \pm SD of four independent assessments. (For abbreviations, see Figure 5). 


\section{$\begin{array}{llll}\text { Control Control+U0126 } & \text { SDT } & \text { SDT }+ \text { U0126 }\end{array}$}
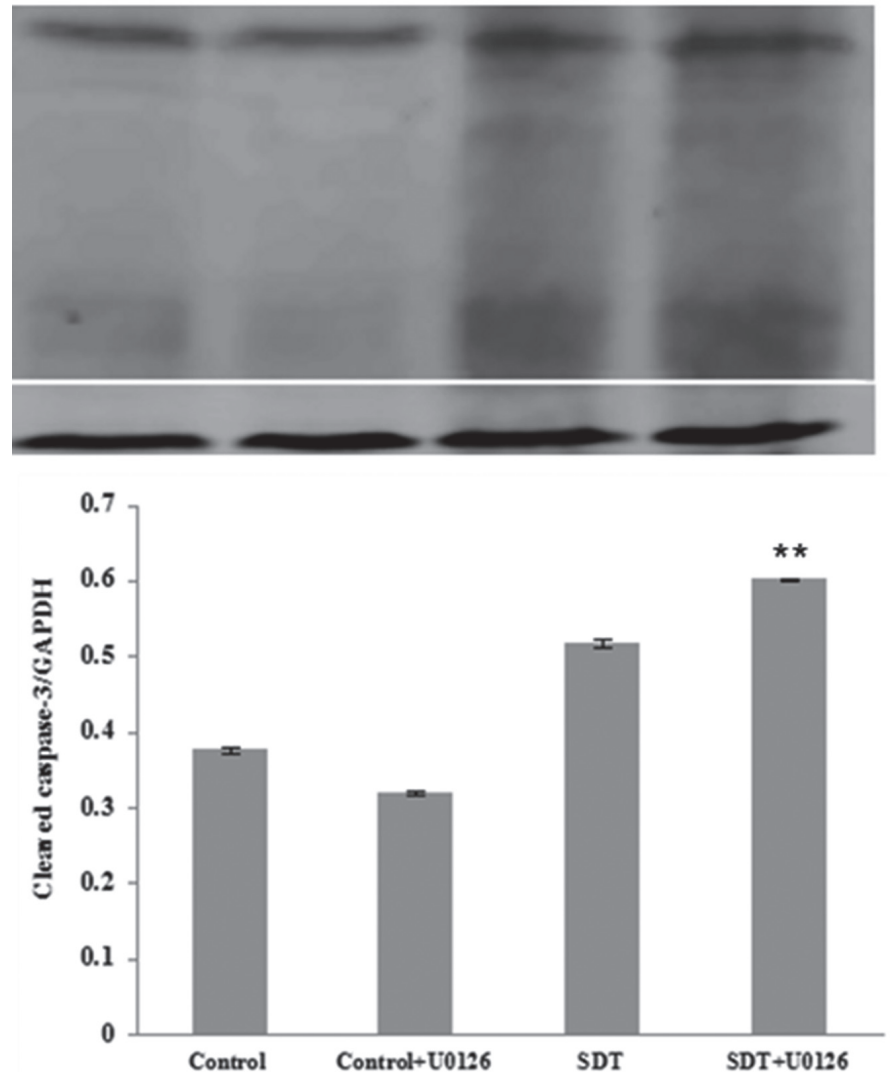

\section{Procaspase-3}

\section{Cleaved caspase-3}

\section{GAPDH}

Figure 12. Western blotting analysis of caspase-3 cleavage in U937 cells after $0.5 \mathrm{~h}$ incubation following SDT treatment with or without ERK inhibitor U0126. Data are presented as mean $\pm \mathrm{SD}$ of four independent assessments. ${ }^{* *} p<0.01$ versus SDT. (For abbreviations, see Figure 5). by an excess of ROS production and energy depletion due to a defective mitochondrial membrane potential (Monick et al. 2008). To confirm this, the generation of intracellular ROS was detected at $0.5 \mathrm{~h}$ after different treatments. Result in Figure 8 showed a rapid generation of intracellular ROS in U0126+ultrasound+Ce6 group and ultrasound+Ce6 group. In the U0126+ultrasound+Ce6 group, there is significant enhancement of ROS production, whereas no obvious occurrence was observed in control and U0126+control alone groups. ROS generation was known to link to the loss of MMP, so we monitored the MMP changes of U937 cells after sonication. The MMP, as detected by flow cytometry with Rh123, was significantly decreased after SDT in the presence of U0126 compared the other three groups (Fig. 9). Taken together, the present study provide strong supports for the crucial role for the ERK pathway in regulating cellular protection in response to oxidative stress, and the ERK inhibitor U0126 was involved in enhancing the sonochemical effects in U937 cells.

In summary, we have demonstrated that Ce6-SDT-induced cytotoxicity and apoptosis in U937 cells could be further enhanced by ERK inhibitor U0126. However, the role of ERK pathway in SDT-mediated cancer therapy still needs further investigations. It is conceivable that combined application of SDT with ERK inhibitor U0126 may prove useful approach in the development of new treatment for leukemia.

The authors declare that they have no conflict of interest.

Acknowledgments. This work was supported by the Natural Science Foundation for Youth (No. 81000999, 10904087), the Fundamental Research Funds for the Central Universities (GK201302022, GK201404004), the Hong Kong Scholars Program (No. XJ2013034) and the Project funded by China Postdoctoral Science Foundation (No. 2014M550477).

\section{References}

Ashush H., Rozenszajn L. A., Blass M., Barda-Saad M., Azimov D., Radnay J., Zipori D., Rosenschein U. (2000): Apoptosis induction of human myeloid leukemic cells by ultrasound exposure. Cancer Res. 60, 1014-020

Boutros T., Chevet E., Metrakos P. (2008): Mitogen-activated protein (MAP) kinase/MAP kinase phosphatase regulation: roles in cell growth, death, and cancer. Pharmacol. Rev. 60, 261-310 http://dx.doi.org/10.1124/pr.107.00106 
Chen Y. R., Wang X., Templeton D., Davis R. J., Tan T. H. (1996): The role of c-Jun N-terminal kinase (JNK) in apoptosis induced by ultraviolet $\mathrm{C}$ and $\mathrm{c}$ radiation. Duration of JNK activation may determine cell death and proliferation. J. Biol. Chem. 271, 31929-31936 http://dx.doi.org/10.1074/jbc.271.2.631

Davis R. J. (2000): Signal transduction by the JNK group of MAP kinases. Cell 103, 239-252 http://dx.doi.org/10.1016/S0092-8674(00)00116-1

El-Najjar N., Chatila M., Moukadem H., Vuorela H., Ocker M., Gandesiri M., Schneider-Stock R., Gali-Muhtasib H. (2010): Reactive oxygen species mediate thymoquinone-induced apoptosis and activate ERK and JNK signaling. Apoptosis 15, 183-195 http://dx.doi.org/10.1007/s10495-009-0421-z

Firestein F., Rozenszajn L. A., Shemesh-Darvish L., Elimelech R., Radnay J., Rosenschein U. (2003): Induction of apoptosis by ultrasound application in human malignant lymphoid cells: role of mitochondria-caspase pathway activation. Ann. N. Y. Acad. Sci. 1010, 163-166 http://dx.doi.org/10.1196/annals.1299.027

Fan Y. S., Gu S. Q., Dong J. G., Dong B. F. (2007): Effects of MEKspecific Inhibitor U0126 on the conidial germination, appressorium production, and pathogenicity of Setosphaeria turcica. Agric. Sci. China 6, 78-85 http://dx.doi.org/10.1016/S1671-2927(07)60019-4

Graves J. D., Draves K. E., Craxton A., Saklatvala J., Krebs E. G., Clark E. A. (1996): Involvement of stress-activated protein kinase and p38 mitogen-activated protein kinase in mIgMinduced apoptosis of human B lymphocytes. Proc. Natl. Acad. Sci. U.S.A. 93, 13814-13818 http://dx.doi.org/10.1073/pnas.93.24.13814

Guyton K. Z., Liu Y., Gorospe M., Xu Q., Holbrook N. J. (1996): Activation of mitogen-activated protein kinase by $\mathrm{H} 2 \mathrm{O} 2$ Role in cell survival following oxidant injury. J. Biol. Chem. 271, 4138-4142 http://dx.doi.org/10.1074/jbc.271.8.4138

Hiraoka W., Honda H., Feril L. B. Jr., Kudo N., Kondo T. (2006): Comparison between sonodynamic effect and photodynamic effect with photosensitizers on free radical formation and cell killing. Ultrason. Sonochem. 13, 535-542 http://dx.doi.org/10.1016/j.ultsonch.2005.10.001

He Y., Xia X., Xu C., Yu H., Bai D., Xiang J., Leung A. W. (2010): 5-Aminolaevulinic acid enhances ultrasound-induced mitochondrial damage in K562 cells. Ultrasonics 50, 777-781 http://dx.doi.org/10.1016/j.ultras.2010.03.004

Honda H., Zhao Q. L., Kondo T. (2002): Effects of dissolved gases and an echo contrast agent on apoptosis induced by ultrasound and its mechanism via the mitochondria-caspase pathway. Ultrasound Med. Biol. 28, 673-682

http://dx.doi.org/10.1016/S0301-5629(02)00509-4

Kuroki M., Hachimine K., Abe H., Shibaguchi H., Kuroki M., Maekawa S., Yanagisawa J., Kinugasa T., Tanaka T., Yamashita Y. (2007): Sonodynamic therapy of cancer using novel sonosensitizers. Anticancer Res. 27, 3673-3677

Krysko D. V., Vanden Berghe T., D'Herde K., Vandenabeele P. (2008): Apoptosis and necrosis: Detection, discrimination and phagocytosis. Methods 44, 205-221 http://dx.doi.org/10.1016/j.ymeth.2007.12.001
Kang C. D., Yoo S. D., Hwang B. W., Kim K. W., Kim D. W., Kim C. M., Kim S. H., Chung B. S. (2000): The inhibition of ERK: MAPK not the activation of JNK:SAPK is primarily required to induce apoptosis in chronic myelogenous leukemic K562 cells. Leuk. Res. 24, 527-534 http://dx.doi.org/10.1016/S0145-2126(00)00010-2

Lagneaux L., de Meulenaer E. C., Delforge A., Dejeneffe M., Massy M., Moerman C., Hannecart B., Canivet Y., Lepeltier M. F., Bron D. (2002): Ultrasonic low-energy treatment a novel approach to induce apoptosis in human leukemiccells. Exp. Hematol. 30, 1293-1301 http://dx.doi.org/10.1016/S0301-472X(02)00920-7

Liu Q., Wang X., Wang P., Qi H., Zhang K., Xiao L. (2006): Sonodynamic effects of protoporphyrin IX disodium salt on isolated sarcoma 180 cells. Ultrasonics 45, 56-60 http://dx.doi.org/10.1016/j.ultras.2006.06.063

Liu Q., Wang X., Wang P., Xiao L., Hao Q. (2007): Comparison between sonodynamic effect with protoporphyrin IX and hematoporphyrin on sarcoma 180. Cancer Chemother. Pharmacol. 60, 671-680 http://dx.doi.org/10.1007/s00280-006-0413-4

Luchetti F., Betti M., Canonico B., Arcangeletti M., Ferri P., Galli F., Papa S. (2009): ERK MAPK activation mediates the antiapoptotic signaling of melatonin in UVB-stressed U937 cells. Free Radic. Biol. Med. 46, 339-351

http://dx.doi.org/10.1016/j.freeradbiomed.2008.09.017

Matsuzawa A., Ichijo H. (2005): Stress-responsive protein kinases in redox-regulated apoptosis signaling. Antioxid. Redox Signal $7,472-481$ http://dx.doi.org/10.1089/ars.2005.7.472

Monick M. M., Powers L. S., Barrett C. W., Hinde S., Ashare A., Groskreutz D. J., Nyunoya T., Coleman M., Spitz D. R., Hunninghake G. W. (2008): Constitutive ERK MAPK activity regulates macrophage ATP production and mitochondrial integrity. J. Immunol. 180, 7485-7496 http://dx.doi.org/10.4049/jimmunol.180.11.7485

Rosenthal I., Sostaric J. Z., Riesz P. (2004): Sonodynamic therapya review of the synergistic effects of drugs and ultrasound. Ultrason. Sonochem. 11, 349-363

Su X., Wang P., Wang X., Cao B., Li L., Liu Q. (2013): Apoptosis of U937 cells induced by hematoporphyrin monomethyl ether-mediated sonodynamic action. Cancer Biother. Radiopharm. 28, 207-217 http://dx.doi.org/10.1089/cbr.2012.1190

Stanton L. A., Beier F. (2007): Inhibition of p38 MAPK signaling in chondrocyte cultures results in enhanced osteogenic differentiation of perichondral cells. Exp. Cell. Res. 313, 146-155 http://dx.doi.org/10.1016/j.yexcr.2006.09.027

Tian Z., Quan X., Xu C., Dan L., Guo H., Leung W. (2009): Hematoporphyrin monomethyl ether enhance sonokilling action of ultrasound on osteosarcoma in vivo. J. Ultrasound Med. 28, 1695-1702

Tang W., Liu Q., Wang X., Mi N., Wang P., Zhang J. (2008): Membrane fluidity altering and enzyme inactivating in sarcoma 180 cells post the exposure to sonoactivated hematoporphyrin in vitro. Ultrasonics 48, 66-73 http://dx.doi.org/10.1016/j.ultras.2007.10.002

Wang X., Martindale J. L., Liu Y., Holbrook N. J. (1998): The cellular response to oxidative stress: influences of mitogen-activated 
protein kinase signalling pathways on cell survival. Biochem. J. 333, 291-300

Wang P., Xu C. S., Xu J., Wang X., Leung A. W. (2010): Hypocrellin $B$ enhances ultrasound-induced cell death of nasopharyngeal carcinoma cells. Ultrasound Med. Biol. 36, 336-342 http://dx.doi.org/10.1016/j.ultrasmedbio.2009.09.007

Yumita N., Sasaki K., Umemura S., Nishigaki R. (1996): Sonodynamically induced antitumor effect of a gallium-porphyrin complex, ATX-70. Jpn. J. Cancer Res. 87, 310-316 http://dx.doi.org/10.1111/j.1349-7006.1996.tb00222.x

Yumita N., Kawabata K., Sasaki K., Umemura S. (2002): Sonodynamic effect of erythrosin B on sarcoma 180 cells in vitro. Ultrason Sonochem 9, 259-265 http://dx.doi.org/10.1016/S1350-4177(02)00080-9

Yumita N., Okuyama N., Sasaki K., Umemura S. (2007): Sonodynamic therapy on chemically induced mammary tumor: pharmacokinetics, tissue distribution and sonodynamically induced antitumor effect of gallium-porphyrin complex ATX70. Cancer Chemother. Pharmacol. 60, 891-897 http://dx.doi.org/10.1007/s00280-007-0436-5

Yu T., Wang Z., Mason T. J. (2004): A review of research into the uses of low level ultrasound in cancer therapy. Ultrason Sonochem 11, 95-103 http://dx.doi.org/10.1016/S1350-4177(03)00157-3

Zhao L. J., Wang L., RenH., Cao J., Li L., Ke J. S., Qi Z. T. (2005): Hepatitis $\mathrm{C}$ virus $\mathrm{E} 2$ protein promotes human hepatoma cell proliferation through the MAPK/ERK signaling pathway via cellular receptors. Exp. Cell. Res. 305, 23-32 http://dx.doi.org/10.1016/j.yexcr.2004.12.024

Received: October 11, 2013

Final version accepted: January 13, 2014 